OPEN ACCESS

Edited by:

Jixin Zhong,

Case Western Reserve University, United States

Reviewed by:

Vineesh Vimala Raveendran, King Faisal Specialist Hospital \&

Research Centre, Saudi Arabia Oreste Gualillo,

Servicio Gallego de Salud, Spain

${ }^{*}$ Correspondence: Karin Wuertz-Kozak kwuertz@ethz.ch

these authors have shared senior authorship.

Specialty section: This article was submitted to Inflammation,

a section of the journal

Frontiers in Immunology

Received: 03 August 2017 Accepted: 15 November 2017 Published: 04 December 2017

Citation:

Monchaux M, Forterre S, Spreng D, Karol A, Forterre F and WuertzKozak K (2017) Inflammatory Processes Associated with Canine Intervertebral Disc Herniation.

Front. Immunol. 8:1681. doi: 10.3389/fimmu.2017.01681

\section{Inflammatory Processes Associated with Canine Intervertebral Disc Herniation}

\author{
Marie Monchaux ${ }^{1}$, Simone Forterre ${ }^{1}$, David Spreng ${ }^{1,2}$, Agnieszka Karol ${ }^{3}$, Franck Forterre ${ }^{1,2 \dagger}$ \\ and Karin Wuertz-Kozak ${ }^{2,4,5,6,7 *+}$

\begin{abstract}
${ }^{1}$ Vetsuisse Faculty, Department of Clinical Veterinary Science, University of Bern, Bern, Switzerland, ${ }^{2}$ Competence Center of Applied Biotechnology and Molecular Medicine (CABMM), University of Zurich, Zurich, Switzerland, ' ${ }^{3}$ vetsuisse Faculty, Institute of Veterinary Pathology, University of Zurich, Zurich, Switzerland, ${ }^{4}$ Department of Health Sciences and Technology, Institute for Biomechanics, ETH Zurich, Zurich, Switzerland, ${ }^{5}$ Schön Clinic Munich, Harlaching, Munich, Germany,

${ }^{6}$ Spine Research Institute, Paracelsus Medical University, Salzburg, Austria, ${ }^{7}$ Department of Health Sciences, University of Postdam, Postdam, Germany
\end{abstract}

Intervertebral disc herniation (IVDH) is an important pathology in humans and also in dogs. While the molecular disease mechanisms are well investigated in humans, little is known about the inflammatory mediators in naturally occurring canine IVDH. The objective of this study was to investigate whether the involved proinflammatory cytokines in human IVDH are also key cytokines in canine IVDH and thus to elucidate the suitability of the dog as a model for human trials. 59 samples from 25 dogs with surgically confirmed thoracolumbar IVDH were collected and classified in three subgroups: herniated $(H)$, affected non-herniated (NH) disc, and adjacent non-affected (NA) disc. Discs from 11 healthy dogs acted as controls (C). Samples were analyzed for IL-1, IL-6, IL-8, and TNF$\alpha$ expression (qPCR/ELISA) as well as cell infiltration and activation of the MAP kinase pathways (immunohistochemistry). Gene and protein expression of all key cytokines could be detected in IVDH affected dogs. Canine IVDH was significantly associated with a higher gene expression of IL-6 $(\mathrm{H}>\mathrm{C}, \mathrm{NH}>\mathrm{C})$ and TNF- $\alpha(\mathrm{H}>\mathrm{C}, \mathrm{NH}>\mathrm{C}$, $N A>C)$ and a significant down-regulation of $\mathrm{IL}-1 \beta(\mathrm{H}<\mathrm{C})$. Dogs with spontaneous pain had significantly higher IL-6 mRNA compared to those with pain arising only upon palpation. An inter-donor comparison $(H$ and $H N$ relative to $N A)$ revealed a significant increase of IL-6 gene expression ( $\mathrm{H}>\mathrm{NA}, \mathrm{NH}>\mathrm{NA})$. IL-8 $(\mathrm{H}>\mathrm{C}, \mathrm{NA}>\mathrm{C})$ and TNF- $\alpha$ $(\mathrm{NH}>\mathrm{C})$ protein levels were significantly increased in diseased dogs while inversely, IL-6 protein levels were significantly higher in patients with better clinical outcome. Aside from resident IVD cells, mostly monocytes and macrophages were found in extruded material, with concomitant activation of extracellular signal-regulated kinase p38 in the majority of samples. Dogs with spontaneous IVDH might provide a useful model for human disc diseases. Although the expression of key cytokines found in human IVDH was also demonstrated in canine tissue, the inflammatory mechanisms accompanying canine IVDH diverges partially from humans, which will require further investigations in the future. In dogs, IL-6 seems to play an important pathological role and may represent a new potential therapeutic target for canine patients.

Keywords: intervertebral disc herniation, inflammatory mediators, IL-1 $\beta$, IL-6, IL-8, TNF- $\alpha$, MAP kinase pathway, canine animal model 


\section{INTRODUCTION}

Intervertebral disc degeneration (IVDD) and intervertebral disc herniation (IVDH) are considered a major cause of acute and chronic low back pain, resulting in a tremendous economic burden worldwide (1-4). IVDD is characterized by progressive structural and functional changes, including a loss of hydrostatic properties of the normally highly hydrated nucleus pulposus (NP) (5), as well as increased vascular and neuronal ingrowth that is associated with chronic back pain (6). Recent human studies have identified proinflammatory cytokines, specifically IL- $1 \beta$, IL-6, IL-8, and TNF- $\alpha$, as pivotal contributors in the course of the pathophysiologic inflammatory cascade of intervertebral disc diseases and the development of neuropathic pain through irritation of ingrowing nerves (7-28). A herniated disc, presented as protrusion, extrusion, or sequestration, is a localized displacement of disc tissue in the epidural space (29), resulting in mechanical compression and chemical irritation of spinal nerves, which contribute to ischemia, radicular symptoms, and stimulation of the inflammatory cascade (30-39). Alongside of heredity $(40,41)$, multiple factors such as age and smoking are involved in the ethiopathogenesis of human IVDD and IVDH as well as in the initiation of an inflammatory cascade (42-45). Furthermore, obesity was highlighted as an important contributor to disc pathologies as it not only increases the load on the IVD (46-48), but also promotes inflammation via cytokine-release from adipocytes and recruited macrophages (49).

Measuring cytokine levels within the diseased tissue can provide a better understanding of the pathological process. As human tissue samples for research-especially as healthy controls-are scarce, more complex pathological investigations and testing of new therapeutic approaches often require animal experiments (50). Currently established models are predominantly based on artificially induced disc pathology through mostly invasive manipulations (e.g., stab incision in rodents), which lack similarities to the human pathology (51). In contrast, animal models based on spontaneously occurring disc pathologies, such as canine IVDH, share important similarities to the clinical presentation, pathology, lesion morphology, diagnostic, treatment, and recovery with human IVDH $(50,52,53)$. IVDH in dogs has an incidence of $2 \%$ of all admissions in referral clinics and occurs predominantly in chondrodystrophic breeds, such as Beagle, Dachshund, Shi-Tzu, and French Bulldog (54-59). Similar to humans, the prevalence of overweight and obesity in dogs is increasing, being as high as $34 \%$ in the US and $25 \%$ in the UK $(60,61)$, with a higher risk factor for disc extrusion in dogs with higher body score index (62). Despite the potential relevance of canine IVDH as a human disease model, little in depth research has been conducted to determine its pathological processes in dogs, specifically regarding the role of inflammatory mediators in disease progression and pain development. Thus far, existing data indicate that in the early phase of canine IVDH, mRNA concentration of IL-6, a possible promoter of inflammation and apoptosis of resident glial cells, was significantly upregulated, whereas returning to baseline values in later stages of the disease. In comparison, mRNA concentration of IL-8, a potent chemokine and early mediator of inflammation, was strongly upregulated in the acute and subacute onset of IVDH. A trend of higher TNF- $\alpha$ mRNA concentration in acute IVDH could also be shown (63). Controversially, Karli et al. demonstrated a downregulation of IL-1 $\beta$, IL- 6 , and TNF- $\alpha$ mRNA concentrations over the whole course of canine IVDH, but highlighted an upregulation of IL- 8 mRNA concentration in the acute stage of the disease, which decreased when treated with non-steroidal anti-inflammatory drugs (64).

Based on the conflicting data found in the current literature, the aim of this study was to identify whether the human key cytokines are expressed in canine IVDs and to determine pathological alterations in their expression by comparing normal IVDs to diseased IVDs with IVDH, with the overall goal to provide further information on the validity of the canine disc disease model. Concomitantly, we also assessed neurologic function, pain status, and clinical outcome in affected dogs.

\section{MATERIALS AND METHODS}

\section{Patients, Controls, and Tissue Samples}

Canine disc material was collected from dogs with confirmed thoracolumbar IVDH during decompressive surgical procedures at our referral institution (November 2013 to February 2015). All samples were collected from actual referred patients and not from laboratory animals. Herniated $(\mathrm{H})$ and non-herniated (NH) IVD samples were both collected from the IVDH: affected level, with $\mathrm{H}=$ prolapsed part and $\mathrm{NH}=$ contained part. Non-affected (NA) IVDs were collected from an adjacent spinal level (prophylactic disc fenestration). Inclusion criteria for IVDH patients: welldocumented records of onset of clinical signs and pretreatment, neurologic findings, diagnosis, course of the disease, ethical approval, and signed owner consent.

In addition, healthy control IVDs (C) were collected from dogs included in an unrelated animal study or patients without any history or signs of spinal disease and without any antiinflammatory pretreatment euthanized for other health reasons. These samples were directly surgically collected after euthanasia within 15 min to avoid potential artifacts in measurements of the cytokines (65-67).

In the patient group, breed, age, gender, duration of neurologic signs, pretreatment, neurologic grade, severity of pain, localization of IVD extrusion, and outcome were recorded. Duration of neurologic signs were defined as the time between the onset of clinical signs and surgery and was grouped as follows: decompression within the first $24 \mathrm{~h}$ after onset of clinical signs (acute), between $24 \mathrm{~h}$ and 7 days of onset (subacute), or after more than 7 days (chronic) $(68,69)$. A complete neurological examination was performed at the time of admission, maximally $12 \mathrm{~h}$ before surgery, at the time at discharge, and at a follow up examination between 2 and 4 weeks after discharge. The neurologic condition and pain were graded as shown in Table $\mathbf{1}(64,70,71)$.

\section{Diagnostic Imaging and Surgical Treatment}

Anesthesia and analgesia were conducted under a standard clinical protocol for each patient (44). Magnetic resonance imaging (MRI) of the thoracolumbar spine was performed (Philips 
TABLE 1 | Clinical scoring system.

\begin{tabular}{|c|c|c|}
\hline Grade & Neurological condition & Pain \\
\hline Zero & & $\begin{array}{l}\text { Neither spontaneous pain (vocalization, } \\
\text { reluctance to move) nor pain on } \\
\text { palpation of the spine }\end{array}$ \\
\hline One & Spinal hyperesthesia only & $\begin{array}{l}\text { No spontaneous pain, but discomfort } \\
\text { (licking, withdrawal) on palpation of } \\
\text { the spine }\end{array}$ \\
\hline Two & Ambulatory paraparesis & $\begin{array}{l}\text { Spontaneous pain and excessive pain } \\
\text { (vocalization, aggressive behavior) on } \\
\text { palpation of the spine }\end{array}$ \\
\hline Three & Non-ambulatory paraparesis & \\
\hline Four & $\begin{array}{l}\text { Paraplegia with intact } \\
\text { nociception }\end{array}$ & \\
\hline Five & Paraplegia without nociception & \\
\hline
\end{tabular}

Panorama HFO, 1.0-T open system, Philips Medical Systems Nederland B.V., The Netherlands) to define the IVD extrusion site. Immediately after MRI, patients underwent surgery for discogenic back pain and to decompress the spinal cord. A standard hemilaminectomy at the site of extrusion, fenestration of the affected and one of the adjacent discs (cranial or caudal) were performed, allowing to take three samples of disc material $(\mathrm{H}$, $\mathrm{NH}$, and NA). For cytokine identification, removed disc material was collected under sterile conditions, snap frozen directly within $15 \mathrm{~s}$ in liquid nitrogen and stored at $-80^{\circ} \mathrm{C}$ until sample preparation. For immunohistochemical and histological analysis, the tissue was fixed in $10 \%$ buffered formalin (1-5 days), embedded in paraffin, and cut into $5 \mu \mathrm{m}$ sections.

\section{Real-time PCR (RT-PCR)}

For RNA isolation, each frozen disc sample was transferred into a precooled custom-made mortar, filled with liquid nitrogen and manually grinded under RNAse free conditions. The frozen tissue powder was transferred into $500 \mu \mathrm{l}$ Trizol (Life Technologies, Van Alben Way, CA, USA), homogenized three times for $30 \mathrm{~s}$ (Polytron PT 2500 E, Kinematica, Luzern, Switzerland), incubated for 5 min at RT and centrifuged at $12,000 \mathrm{~g}$ for $10 \mathrm{~min}$ at $4^{\circ} \mathrm{C}$.

The supernatant was mixed with $250 \mu \mathrm{l}$ chloroform, vortexed for $30 \mathrm{~s}$, incubated at RT for $15 \mathrm{~min}$, centrifuged at $12,000 \mathrm{~g}$ for $15 \mathrm{~min}$ at $4^{\circ} \mathrm{C}$ and the aqueous phase recovered. RNA was precipitated by adding $125 \mu$ isopropanol and $125 \mu$ lof high salt precipitation solution $(0.8 \mathrm{M}$ sodium citrate, $1.2 \mathrm{M}$ sodium chloride), washed with $500 \mu \mathrm{l}$ of $75 \%$ ethanol and dissolved in $25 \mu \mathrm{l}$ RNase free water after complete removal of ethanol. The quantity of the isolated RNA was determined spectroscopically (NanoDrop ${ }^{\circledR}$ Lite, Thermo Fisher Scientific, Wilmington, DE, USA) and the quality confirmed by the sample's OD 260/280 (1.8-2.0; samples with lower quality were excluded from further analyses). cDNA was prepared using the TaqMan Reverse Transcription kit (TaqMan ${ }^{\circledR}$ Reverse Transcription Reagent, Life Technologies, Van Alben Way, CA, USA) according to the manufacturer's instruction. RT-qPCR was conducted on the CFX96 Touch qPCR Machine (Bio-Rad Laboratories, Hercules, CA, USA) as previously described $(46,47)$, by mixing $5 \mu$ l of TaqMan ${ }^{\circledR}$ Fast Advanced Master Mix (Life Technologies, Van Alben Way,
TABLE 2 | TaqMan primers/probes and sequence accession number.

\begin{tabular}{llc}
\hline Target gene & Assay number & Accession number \\
\hline IL-1 $\beta$ & Cf02671951_g1 & NM_001037971.1 \\
IL-6 & Cf02624282_m1 & NM_001003301.1 \\
IL-8 & Cf02624283_m1 & NM_001003200.1 \\
TNF- $\alpha$ & Cf02624261_m1 & NM_001003244.4 \\
TATA box-binding protein (TBP) & Cf02637232_m1 & XM_005627735.2
\end{tabular}

CA, USA) with 10 ng cDNA in RNAse free water ( $4.5 \mu$ in total) and $0.5 \mu \mathrm{l}$ of canine TaqMan primers/probes (TaqMan ${ }^{\circledR}$ Gene Expression Assays, Life Technologies, Van Alben Way, CA, USA) (Table 2).

Each sample was run in duplicate for each gene, the CT value means were calculated and the comparative CT method was used for data evaluation [relative quantification (RQ)]. Samples with gene expression lower than the detection limit were attributed an artificial maximal CT value of 43 , using the selection of the median as aggregation method between samples with the same experimental condition to avoid statistical and mathematical issues (72).

For group comparisons between $\mathrm{H}, \mathrm{NH}, \mathrm{NA}$, and $\mathrm{C}$, results were calculated as $2^{-\Delta \mathrm{CT}}$ values, i.e., the expression of each target gene was normalized relative to the expression of the house keeping gene [canine TATA box-binding protein (TBP)], using the classical $\Delta$ CT method and the following algorithm:

$$
\left.\mathrm{RQ}=2^{-\left(\mathrm{Ct}(\mathrm{H})_{\text {Target Gene }}-\mathrm{Ct}(\mathrm{H})_{\text {T⿱R⿴囗十 }}\right)} \text { (identically for } \mathrm{NH}, \mathrm{NA}, \mathrm{C}\right) \text {. }
$$

For interdonor calculations, an additional normalization step $(\Delta \Delta \mathrm{CT})$ was performed $(\Delta \mathrm{CT}$ of $\mathrm{H}$ or $\mathrm{NH}$ minus $\Delta \mathrm{CT}$ of $\mathrm{NA}$, of the same animal). Results were calculated as $2^{-\Delta \Delta \mathrm{CT}}$ values and shown as fold change in expression between affected discs $(\mathrm{H}$, $\mathrm{NH}$ ) and internal control discs (NA). The following algorithm was used:

$\mathrm{RQ}=2^{-\left[\left(\mathrm{Ct}(\mathrm{H})_{\text {Target Gene }}-\mathrm{Ct}(\mathrm{H})_{\mathrm{TBP}}\right)-\left(\mathrm{Ct}(\mathrm{NA})_{\text {Target Gene }}-\mathrm{Ct}(\mathrm{NA})_{\mathrm{TBP}}\right)\right]}$ (identically for $\left.\mathrm{NH}\right)$.

The intra-assay CV was $0.74 \%(n=131)$.

\section{Total Protein and ELISA}

ELISA samples were weighed and pulverized as described above, but with immersion in T-PER reagent (Tissue Protein Extraction Reagent, Thermo Fisher Scientific, Wilmington, DE, USA) at a ratio of $100 \mu \mathrm{T}$-PER reagent per $10 \mathrm{mg}$ tissue. The lysates were homogenized and purified following a standardized protocol. Briefly, samples were centrifuged at $12,000 \mathrm{~g}$ at $4^{\circ} \mathrm{C}$ for $10 \mathrm{~min}$, the supernatant was collected and total protein was determined by the Bradford assay (Bio-Rad Protein Assay Dye Reagent Concentrate, Bio-Rad Laboratories, Hercules, CA, USA), with absorbance measurement at $585 \mathrm{~nm}$ (Infinite ${ }^{\circledR} 200$ Pro, Tecan Group Ltd., Männedorf, Switzerland). The protein levels of IL-1 $\beta$, IL-6, IL-8, and TNF- $\alpha$ were detected with canine specific ELISAs (MyBioSource, San Diego, CA, USA for IL-1 $\beta$, IL-6, IL-8, and Quantikine ELISA Kit, R\&D Systems Inc., Minneapolis, MN, USA, for TNF- $\alpha$ ) according to the manufacturer's instructions, with a sensitivity of $1 \mathrm{pg} / \mathrm{ml}$ for IL- $1 \beta$, IL- 6 , and IL- 8 kit and 
$4.2 \mathrm{pg} / \mathrm{ml}$ for TNF- $\alpha$. Sample concentration was calculated based on a standard curve and normalized to total protein content. Results are demonstrated either as group comparisons $(\mathrm{H}, \mathrm{NH}$, $\mathrm{NA}, \mathrm{C}$ : cytokine content/total protein in $\mathrm{pg} / \mathrm{mg}$ ) or as interdonor comparisons ( $\mathrm{H}$ and $\mathrm{NH}$ relative to NA: fold change). The median intra-assay $\mathrm{CV}$ is $9.0 \%$ (range $5.3-15 \%$ ) and the median interassay CV $10.8 \%$ (range $9.3-15 \%$ ), as provided by the supplier.

\section{Immunohistochemistry}

Serial sections were deparaffinized, heat-mediated antigen retrieval was conducted $\left(95^{\circ} \mathrm{C}, 20 \mathrm{~min}\right)$ and sections were incubated with primary antibodies (RT, overnight) identifying infiltrating cells (polymorphonuclear, mononuclear, macrophages, multinucleated giant cells) and MAP kinase (MAPK) pathway activation (Table 3). Subsequently, sections were treated with an appropriate primary antibody (Marker) and washed $3 \times$ with Tris buffer before the secondary antimouse IgG was applied (1:200 dilution, $30 \mathrm{~min}$ ). The amino-9-ethyl-carbazole substrate kit (Dako) was employed as a chromogen. Finally, the sections were counter-stained with Gill's hematoxylin for $3 \mathrm{~min}$, and cover-slipped with an aqueous mounting media (Glicerine, Sigma-Aldrich).

All slides were examined and semiquantitatively evaluated independently by two investigators for infiltrating cell types in the extruded NP as well as activation of the MAPK pathway [c-Jun NH2-terminal kinase (JNK), p38 isoforms of MAPK (p-38), extracellular signal-regulated kinases (ERKs)]. The following grades were used: $(-)$ negative; $( \pm)$ weakly (less than $5 \%$ of cells positive); (+) moderately (5-25\% of cells positive); (++) strongly (more than $25 \%$ of cells positive).

\section{Statistical Analysis}

For all results, an outlier calculation was performed and outliers removed before statistical analysis (MedCalc 16.8/2016, http:// www.medcalc.org). Summary statistics were performed and normality assessed using D’Agostino-Pearson tests. As data were versatile regarding its distribution, nonparametric statistics were additionally used except for the interdonor comparison. A Kruskal-Wallis test was used to identify any association between gene and protein expression of cytokines with location of IVDH, duration of clinical signs, neurologic grade, pretreatment and outcome. Differences in gene or protein expression of cytokines between the samples of affected and control animals were evaluated using a Mann-Whitney $U$-test. The subgroup

TABLE 3 | Detailed antibody information.

\begin{tabular}{lllll}
\hline Marker & Provider & Order nr. & Dilution & Read-out \\
\hline CD18 & P. Moore & CA16.3C10 & $1: 10$ & Cell infiltration \\
CD3 & Dako & A0452 & $1: 600$ & \\
VWF8 & Dako & M0616 & $1: 400$ & \\
p-JNK & Cell Signaling & PA5-21343 & $1: 50$ & MAP kinase \\
& Technologies & & & activation \\
p-p38 & Cell Signaling & ab32142 & $1: 50$ & \\
& Technologies & & & \\
p-ERK1/2 & Cell Signaling & MAl-13041 & $1: 50$ & \\
& Technologies & & &
\end{tabular}

comparison was carried out stepwise by a Wilcoxon signed-rank test. The Bonferoni $p$-value adjustment was used to control for multiple comparisons. For inter-donor comparisons of gene and protein expression, an independent sample $t$-test and a MannWhitney $U$-test was performed, respectively. A Spearman's rank correlation was used to examine the relationship between gene expression and protein level. Threshold value for statistical significance was set up to $p<0.05$ and data are presented as boxplots, with median and $95 \%$ confidential interval (CI) unless otherwise stated.

\section{RESULTS}

\section{Clinical Data}

Twenty-five dogs with surgically confirmed thoracolumbar IVDH were included in the study. All canine patients (25 of 25 cases) were small and medium-breed dogs ( $<20 \mathrm{~kg})$ with a median body weight at admission of $9.0 \mathrm{~kg}$ (range $3.6-19.0 \mathrm{~kg}$ ). The dogs were classified as chondrodystrophic breeds with the Dachshund $(n=5)$, Cocker Spaniel, Coton de Tuléar and the French Bulldog (each $n=2$ ) and the Bichon Frisé, Cavalier King Charles Spaniel, Jack Russel Terrier, Pekingese, Miniature Poodle, Pug Dog, Shi-Tzu, and the Yorkshire Terrier (each $n=1$ ) or as non-chondrodystrophic or mixed breeds with the Border Collie $(n=1)$ and the Mixed Breed Dog $(n=5)(57,73,74)$. The median age was 5 years (range $3-13$ years). Sixteen dogs were male intact, four were female intact, three were female spayed, and two were male castrated. The median duration of clinical signs until surgery was 3 days (range 1-365 days). When classified into three groups, there were 3 acute, 14 subacute, and 8 chronic cases. Ten dogs were referred without pretreatment, five had been pretreated with steroids, seven with NSAIDs, and three with a combination of both, pooled together as pretreated dogs. The neurologic status before surgery was Grade 2 in 11, Grade 3 in 6, Grade 4 in 5, and Grade 5 in 5 dogs. Pain score revealed 2 dogs with Grade 0, 14 dogs with Grade 1, and 9 animals with Grade 2. The spinal level of IVDH in the affected dogs were L2-L3 in eight dogs, Th12-Th13 in six dogs, Th11-Th12, L1-L2, L3-L4 in each three dogs, and Th10-Th11, Th13-L1 in each one dog. Fifteen dogs had a good outcome, six showed an improvement, but were not ambulatory, and four showed no improvement within 1 month after surgery. In the latter case, two of them were euthanized because of poor prognosis, a follow-up call unveiled that the other two dogs are still in physiotherapy treatment showing no improvement in the last 7 and 9 months.

Eleven euthanized dogs without signs of IVDH were included as control group. The median age of the control group was 4.5 years (2-11 years). Ten dogs were female spayed and one dog was female intact. There were 10 beagles and 1 was a mixed breed dog.

\section{Diagnostic Imaging and Surgical Treatment}

All 25 affected dogs underwent surgical decompression of the spinal cord immediately after diagnostic imaging, including the collection of the samples. Three different samples $(\mathrm{H}, \mathrm{NH}$, and NA) were collected in 14 dogs, two different samples $(\mathrm{H}$, 
$\mathrm{NH}$ ) in 6 dogs, and one sample (H) in 5 dogs, resulting in a total of 59 samples. The median sample weight was $30.62 \mathrm{mg}$ (range 1.7-112.3 mg). Six disc samples were excluded: four NHs and one $\mathrm{H}$ were excluded due to very small size and one $\mathrm{NH}$ sample demonstrated inconsistent housekeeping gene expression and out of range protein values. From the remaining 53 samples, 11 tissue samples weighting more than $50 \mathrm{mg}$ were equally divided in samples for PCR and ELISA testing. 18 smaller samples were solely assigned to PCR testing and 24 smaller samples solely to ELISA testing. In the $\mathrm{C}$ group, we collected 11 samples in 11 dogs in the Th13-L1-L2 IVD space, with a median sample weight of $60.87 \mathrm{mg}$ (range 30.3-133 mg). One dog was completely omitted because of RNA impurity. From the 10 remaining control samples, 4 samples weighting more than $50 \mathrm{mg}$ were equally split into samples for PCR and ELISA. Three samples each were solely assigned to PCR and ELISA testing.

\section{Cytokine Detectability}

We could demonstrate gene and protein expression of the selected proinflammatory cytokines IL- $1 \beta$, IL-6, IL-8, and TNF- $\alpha$ in IVDH in dogs.

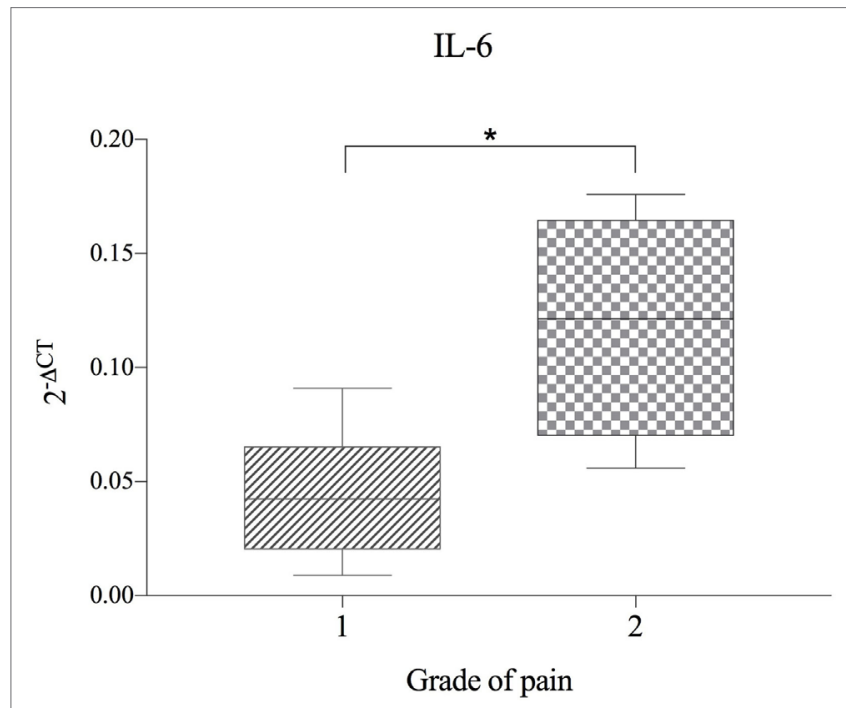

FIGURE 1 | Gene expression of IL-6 in herniated disc material, compared between dogs with differing grade of pain $(n=11)$ and shown as $2^{-\Delta C T}$. Grade 1 = no spontaneous pain, but discomfort upon palpation of the spine. Grade 2 = spontaneous pain and excessive pain upon palpation of the spine. Asterisks indicate statistical significance between groups at $p<0.05\left(^{*}\right)$.

\section{Gene Expression}

No significant correlation between IVDH location, duration of clinical signs or outcome, and the genes of interest was demonstrated, but the gene expression of IL-6 was significantly higher $(p=0.043)$ in pain grade 2 compared to grade 1 (Figure 1). Pooled results of all dogs in the respective groups $(\mathrm{C}, \mathrm{H}, \mathrm{NH}, \mathrm{NA})$ showed a significant downregulation of IL-1 $\beta$ in $\mathrm{H}$ compared to C, but no difference between NH or NA and C was found. IL-6 expression was significantly higher in $\mathrm{H}$ and $\mathrm{NH}$ compared to $\mathrm{C}$, but not in NA. TNF- $\alpha$ expression showed significantly higher levels in $\mathrm{H}, \mathrm{NA}$, and $\mathrm{NH}$ compared to $\mathrm{C}$. Gene expression of IL-8 showed no significant difference among the groups. All results are shown in Table 4 and Figure 2.

As patients demonstrated differences in their basal cytokine levels, hence resulting in high donor-donor variations in subgroup comparisons, an interdonor comparison was conducted ( $\mathrm{H}$ and $\mathrm{HN}$ relative to $\mathrm{NA}=$ internal control for each patient). A significant increase of IL- 6 was observed for $\mathrm{H}$ and $\mathrm{NH}$ compared to NA. In contrast, gene expression of IL- $1 \beta$, IL- 8 , and TNF- $\alpha$ were either unchanged or reduced in diseased compared to NA IVDs. All results are shown in Table 5 and Figure 3.

\section{Protein Expression}

There were no significant correlations between cytokine protein levels and IVDH location, severity of pain, pretreatment or outcome and concentration of cytokines, but IL- 6 was found to be significant higher in the clinical outcome group 2 compared to group 1 (Figure 4).

No significant differences of IL- $1 \beta$ or IL- 6 protein expression were observed between the various groups. The concentration of IL-8 was significantly higher in $\mathrm{H}$ and NA compared to $\mathrm{C}$, but no difference was found between $\mathrm{NH}$ and C. TNF- $\alpha$ showed significantly higher protein levels in $\mathrm{NH}$ compared to $\mathrm{C}$, but not for H or NA. Results are shown in Table 6 and Figure 5.

Like for gene expression, an additional inter-donor comparison was conducted, with NA as the internal control. However, no statistical differences were found between diseased $(\mathrm{H}, \mathrm{NH})$ and NA IVDs due to a level of variability and low sample numbers (data not shown).

No significant relationship was found between gene expression and corresponding protein concentration (IL- $1 \beta r \mathrm{~s}=0.02$; 95\% CI, $-0.66-0.67, p=0.97 ; I L-6 r s=0.30 ; 95 \% \mathrm{CI},-0.41-0.78$; $p=0.41$; IL-8 $r s=-0.25,95 \% \mathrm{CI},-0.85-0.62, p=0.59$; TNF$\alpha r s=-0.51,95 \% \mathrm{CI},-0.86-0.18, p=0.13)$. Interestingly, a significant association in gene expression between IL- 6 and IL-8 ( $r s=0.79,95 \%$ CI $0.08-0.97, p=0.036$ ) was found in the control

TABLE 4 | Statistical results of gene expression data (subgroup comparison, independent samples).

\begin{tabular}{|c|c|c|c|c|c|}
\hline Cytokine & Control IVD & Median (95\% Cl) & Comparative IVD & Median (95\% Cl) & $p$-Value \\
\hline $\mathrm{IL}-1 \beta$ & $\mathrm{C}$ & 10.556 (5.927-27.650) & $\mathrm{H}$ & $1.798(0.329-7.156)$ & 0.018 \\
\hline IL-6 & C & $0.012(0.004-0.052)$ & $\begin{array}{c}\mathrm{H} \\
\mathrm{NH}\end{array}$ & $\begin{array}{l}0.057(0.034-0.139) \\
0.178(0.045-1.114)\end{array}$ & $\begin{array}{l}0.013 \\
0.006\end{array}$ \\
\hline $\mathrm{TNF}-\alpha$ & $\mathrm{C}$ & $0.007(0.001-0.022)$ & $\begin{array}{l}\mathrm{H} \\
\mathrm{NA} \\
\mathrm{NH}\end{array}$ & $\begin{array}{l}0.112(0.036-0.230) \\
0.087(0.024-0.186) \\
0.060(0.019-0.080)\end{array}$ & $\begin{array}{l}0.008 \\
0.008 \\
0.007\end{array}$ \\
\hline
\end{tabular}




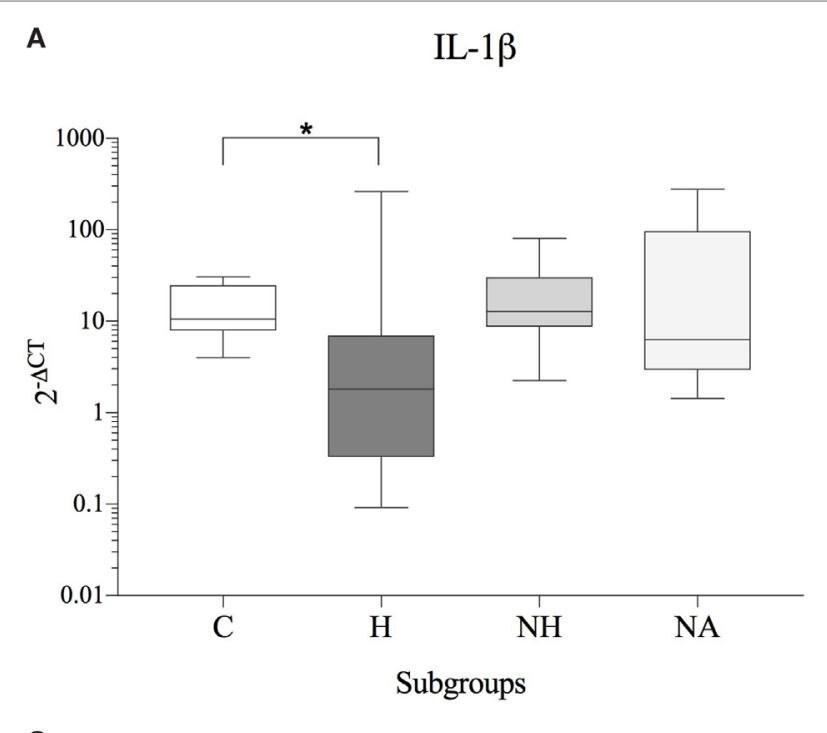

C

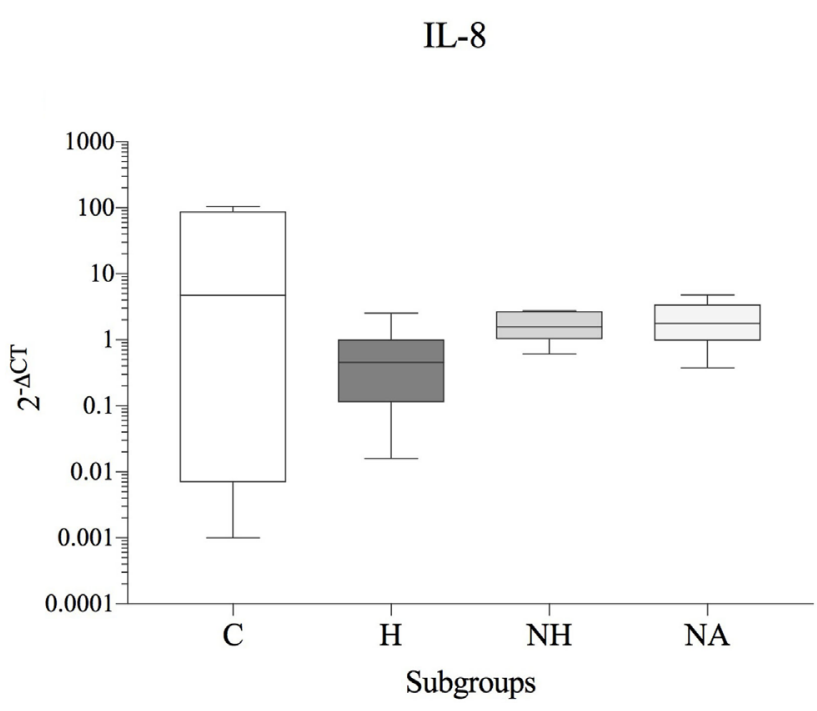

B

IL-6

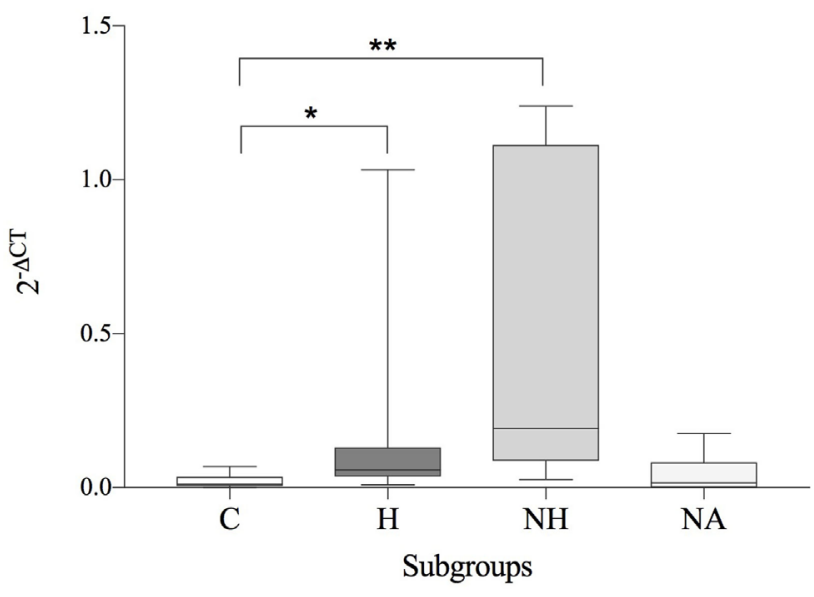

D

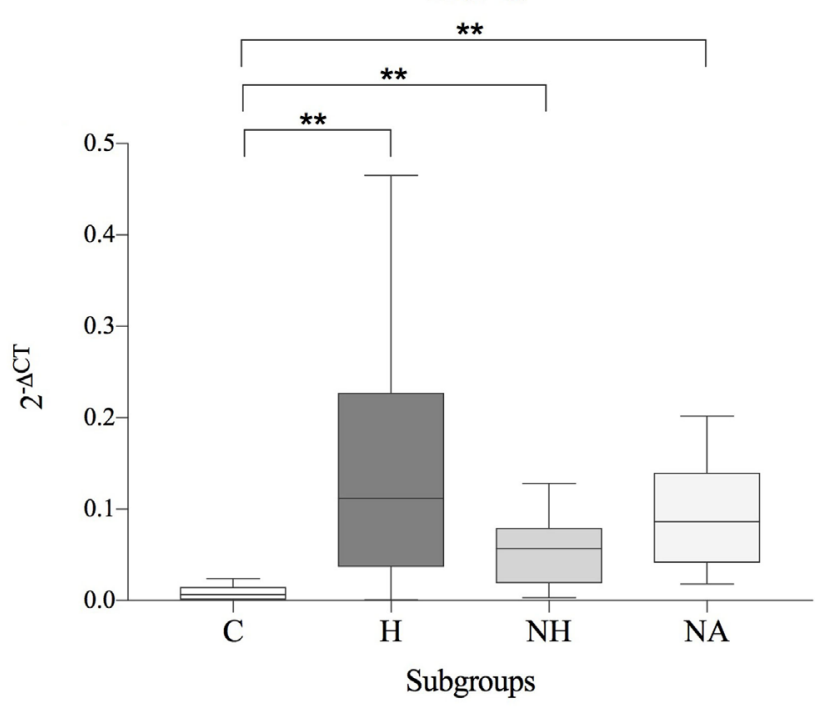

FIGURE 2 | Gene expression data (subgroup comparison, independent samples, $n \geq 6$ per subgroup) of (A) IL-1 $\beta$, (B) IL-6, (C) IL-8, and (D) TNF- $\alpha$, compared between herniated $(\mathrm{H})$, non-herniated $(\mathrm{NH})$, non-affected $(\mathrm{NA})$ as well as healthy control $(\mathrm{C})$ intervertebral disc material. Data are shown as $2^{-\Delta C T}$. Asterisks indicate statistical significance between groups at $p<0.05\left(^{(*)}\right.$ and $p<0.01{ }^{(*)}$.

TABLE 5 | Statistical results of interdonor gene expression data (subgroup comparison, dependent samples).

\begin{tabular}{llcrc}
\hline Cytokine & Control IVD & Comparative IVD & Median (95\% Cl) & $\boldsymbol{p}$-Value \\
\hline IL-6 & NA & $H$ & $498.625(3.722-20,901.118)$ & 0.031 \\
& & $\mathrm{NH}$ & $2,473.292(158.129-43,724.429)$ & 0.031 \\
\hline
\end{tabular}

group. In herniated samples, IL-1 $\beta$ protein correlated with IL-6 ( $r s=0.71 ; 95 \% \mathrm{CI}, 0.36-0.88, p=0.001)$, IL-8 $(r s=0.54 ; 95 \% \mathrm{CI}$, $0.09-0.80, p=0.02)$ as well as TNF- $\alpha$ concentrations $(r s=0.55$; $95 \%$ CI, $0.11-0.81, p=0.02$ ) measured by ELISA.

\section{Immunohistochemistry}

Monocytes and macrophages were the most infiltrating cell population encountered in canine herniated IVD material.
Sporadically, giant cells resembling notochordal cells were observed. CD 18 was highly expressed $(++)$ in all samples, whereas detection of CD3 and vWF8 detection was semiintractable and error-prone, hence not being shown. Expression of activated (phosphorylated) ERK $(++)$ (Figure 6) and p38 $(+/++)$ could be detected in most of the examined slides, whereas pJNK $(-/+)$ was only sporadically detectable (not shown). 

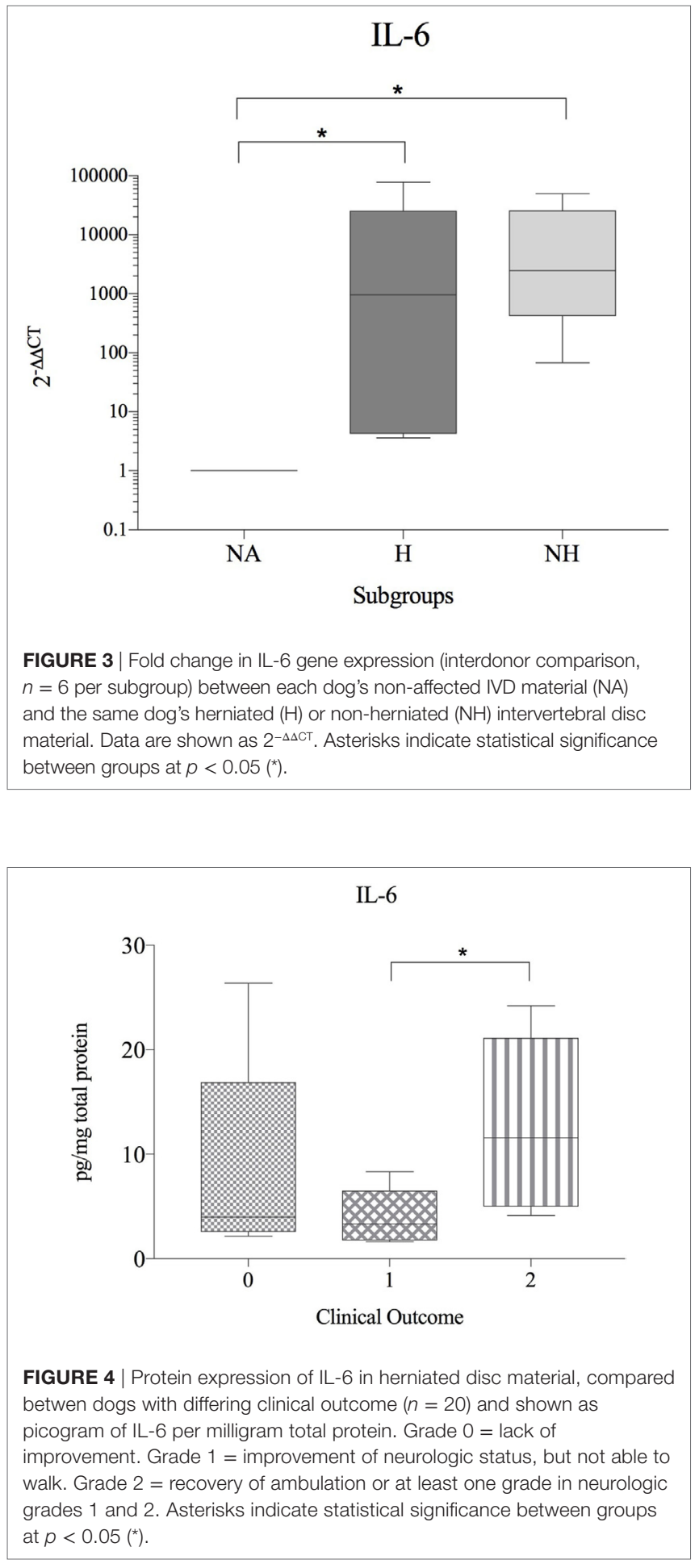

\section{DISCUSSION}

Previous research on human IVD tissue has demonstrated that degeneration and herniation coincides with increased levels of inflammatory mediators, such as IL- $1 \beta$, IL-6, IL- 8 , and TNF- $\alpha$ (8). In the present study, a comparison between diseased (herniated IVDs $=\mathrm{H} ; \mathrm{NH}$ ) and control (C) IVDs of dogs demonstrated that disc disease was associated with significantly higher gene expression of IL-6 (H vs. C, NH vs. C) and TNF- $\alpha$ (H vs. C, NH vs. C). On the protein level, a significant increase of IL-8 and TNF- $\alpha$ in IVDs of diseased dogs compared to controls was found. A patient-specific comparison between the diseased $(\mathrm{H}, \mathrm{NH})$ and the IVDs excised from an adjacent level (NA) of the same dog revealed a pronounced pathological elevation of IL-6 ( $\mathrm{H}$ vs. NA, $\mathrm{NH}$ vs. NA). In contrast, mRNA levels of IL- $1 \beta$, IL- 8 , and TNF- $\alpha$ were either unchanged or reduced in diseased compared to NA IVDs of patients.

Previous studies on canine disc disease found IL- $1 \beta$ to be either undetectable or downregulated in dogs, which contrasts human disc pathology $(64,75)$. This was confirmed by our findings, showing a significant downregulation of the gene expression of IL-1 $\beta$ in herniated disc material $(\mathrm{H})$ compared to controls, a downregulation in the affected disc material $(\mathrm{H}, \mathrm{NH})$ of the paired samples and no significant findings on the protein level.

In human IVDH, higher protein levels of the proinflammatory cytokine IL- 6 were detected in different studies $(10,23,25$, $76)$, hence being discussed as a prognostic factor and therapeutic target. Thus far, results on IL-6 expression during canine disc disease are contradictory $(63,64,75,77)$. According to our findings, IL-6 seems to have a pivotal role, with its gene expression being significantly upregulated in the affected disc material $(\mathrm{H}$, $\mathrm{NH}$ ) of the independent and paired samples, unrelated to the duration of the clinical signs. Interestingly, we noticed a correlation between IL- 6 mRNA levels and the severity of pain, with mRNA expression being significantly higher in those canine patients with basal pain than in those with pain arising only upon palpation. To the authors' knowledge, this has not been described before in canine IVDH, but might be in accordance with recent research in humans that has increasingly pointed toward IL-6 being a crucial factor in pain development (78, 79). However, IL-6 is not only a proinflammatory cytokine with significance in inflammation and diseases, but is also known to have regenerative or anti-inflammatory properties (80). Our results indicated that canine patients showing higher concentration of IL-6 protein levels in their IVD had a better outcome and were more likely to regain ambulation. This contrasting finding might be explained by the dual function of IL-6, suggesting that with time, IL- 6 might control inflammation by acting as an antiinflammatory cytokine $(81,82)$. IL-6 originates directly from

TABLE 6 | Statistical results of protein expression data (subgroup comparison, independent samples).

\begin{tabular}{|c|c|c|c|c|c|}
\hline Cytokine & Control IVD & Median $(95 \% \mathrm{Cl})$ & Comparative IVD & Median $(95 \% \mathrm{Cl})$ & $p$-Value \\
\hline
\end{tabular}




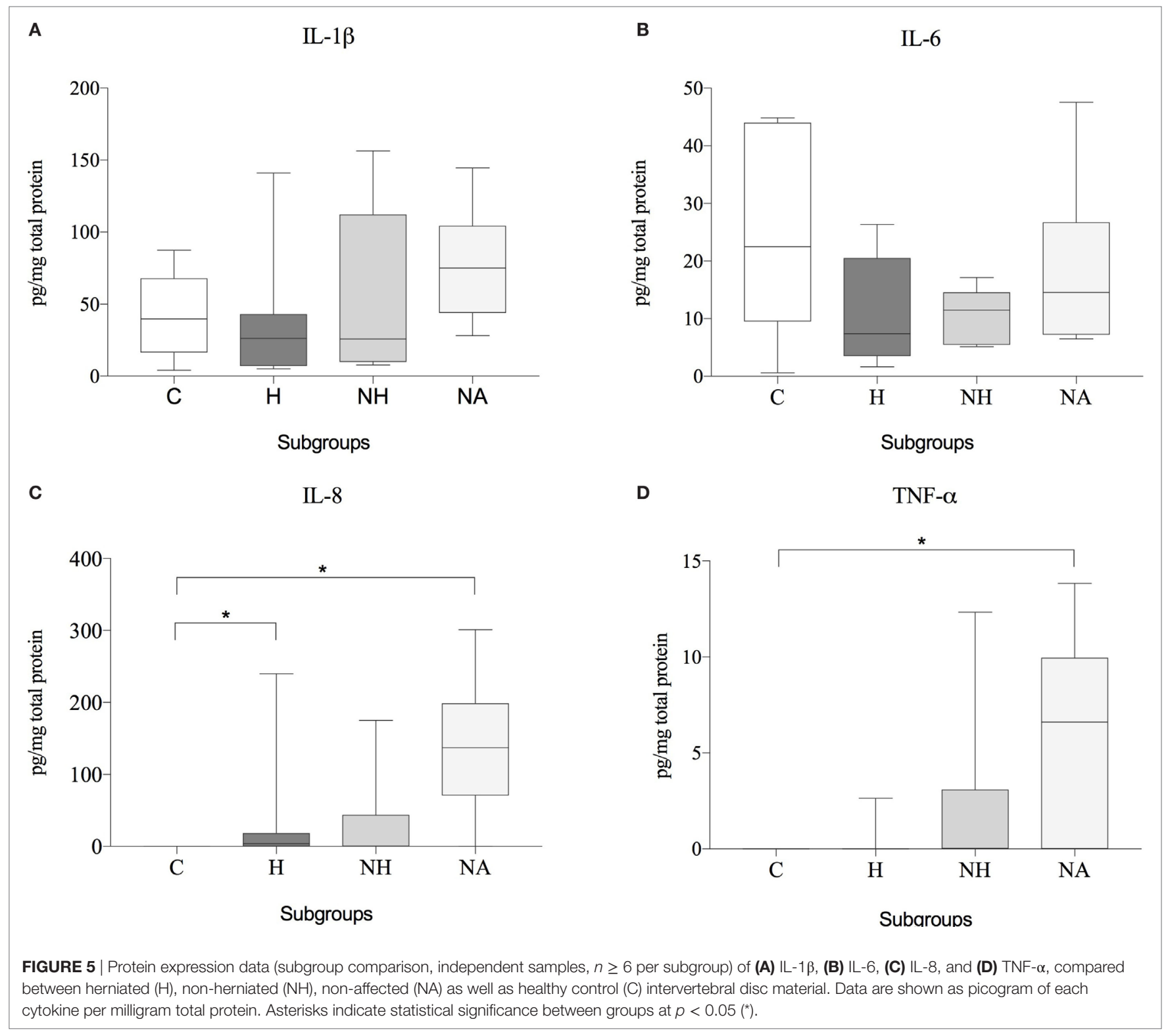

IVD cells (76) and also from T-cells and macrophages (83-86), the latter constituting the main cell population of the inflammatory infiltrates in the epidural space after IVD extrusion in our samples. Based on our findings, IL- 6 could potentially have also a beneficial role in the late onset of the inflammatory cascade of canine IVDH. Therefore, therapeutic blockage for IL-6 should be carefully considered.

In this study, we also analyzed the expression of IL-8, which has previously been shown to be strongly upregulated in the acute phase of canine IVDH $(63,64,77)$, yet with a negative correlation between its expression and the duration of spinal cord injury secondary to IVDH (77). As IL-8 is thus thought to be an early disease marker with time-dependent expression and as our patients were mostly seen for treatment at a late stage of the disease, it explains why we could not demonstrate a significant upregulation of IL- 8 mRNA, but of IL- 8 protein in diseased discs.
Interestingly, a significant upregulation of the protein level of IL-8 in independent samples could as also be demonstrated in NA disc material, suggesting a possible secretion of IL- 8 in canine disc material before the effective herniation of the affected IVD and hence further supporting a possible early stage inflammation as a trigger for IVDH.

Together with IL- $1 \beta$, TNF- $\alpha$ is likely the most studied cytokine in human $\operatorname{IVDD}(11,17,28,87,88)$, inducing matrix degrading enzyme expression and upregulation of nerve growth factor. TNF- $\alpha$ is hence suggested to be have an important role in the development of hyperalgesia and chronic pain after IVDH in humans $(7,16,28,89-92)$. Contradictory results have been found on TNF- $\alpha$ expression in canine IVDH, ranging from non-detectability $(64,75,77)$ to disease-related elevation (albeit non-significant) (63). In accordance with Spitzbart et al. (63), as well as with human studies, we could demonstrate a significant 

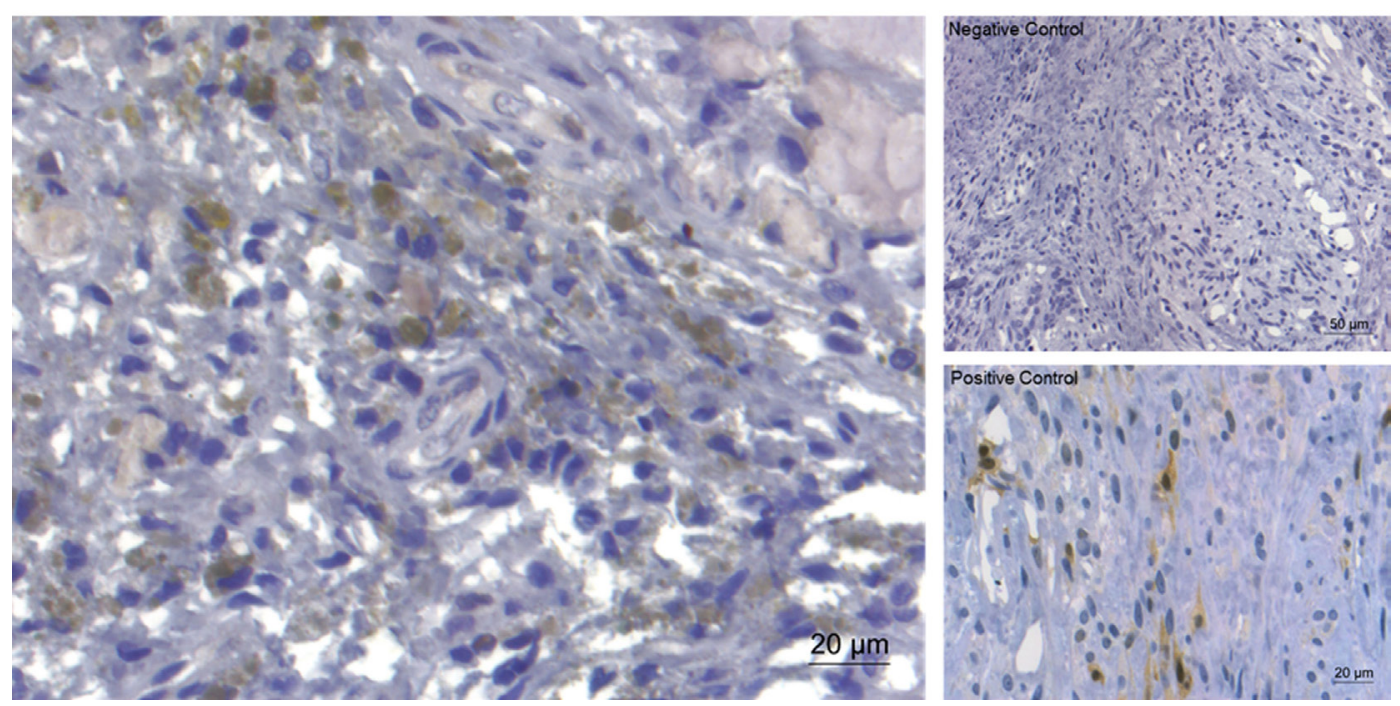

FIGURE 6 | Immunohistochemical staining for extracellular signal-regulated kinase (ERK)1/2 of extruded canine intervertebral disc material (left). Expression of ERK (brownish coloration) was detected in the majority of the examined slides. On the right, negative control and positive control (canine mammar carcinoma) are depicted.

upregulation of TNF- $\alpha$ on the gene expression level $(\mathrm{H}, \mathrm{NH})$ and the protein expression level (NH). Furthermore, and also similar to human NP samples in which TNF- $\alpha$ is known to be continuously expressed at basal levels (93), TNF- $\alpha$ could also be detected in adjacent discs (NA) suggesting to be a possible trigger of an early stage inflammation for IVDH.

Histological investigations demonstrated that most herniated IVDs exhibited an epidural inflammatory response, ranging from acute invasion of neutrophils to formation of chronic granulation tissue. Histological analysis of underlying inflammatory pathways demonstrated activation of the MAPKs ERK and p38 in most samples, whereas pJNK was rarely detected. MAPKs are signal transduction pathways that are activated by a multitude of stimuli, ranging from environmental, mechanical and osmotic stress to growth factors, cytokines and reactive oxygen species, with ERK and p38 controlling inflammation, catabolism as well as cell growth, differentiation and viability/death (27). The fact that the MAPKs pathways are shared between the cytokines might explain the correlation on the protein level in herniated samples of IL- $1 \beta$ with IL-6, IL- 8 , and TNF- $\alpha$ (94).

In accordance with our results, in vitro cell culture studies and rodent in vivo studies have previously demonstrated that p38 and ERK are activated in inflammatory environments (95-100), controlling a variety of metabolic functions associated with disc pathology, including proteoglycan degradation $(96,97)$. Furthermore, the decrease in osmotic pressure observed during herniation in our canine patients may also play a causative role in MAPK activation as previously demonstrated for bovine IVDs and the ERK pathway (101). Importantly, activation of p38 and ERK in our canine samples may not only induce downstream expression of additional inflammatory mediators and matrix degrading enzymes and hence play an important role in disease progression [reviewed in Ref. (27)], but may furthermore be a means to initiate resorption of non-contained herniated disc tissue (102-104).

Despite providing interesting new findings on the inflammation in canine IVDH, the present study has several limitations that should be considered. The dog size as well as the morphologic size of the herniated disc tissue imposed limitations on the number of performed tests. The quantity of surgically excised canine disc material is smaller than specimens collected in humans. Therefore, we could not divide all samples equally for PCR and ELISA testing as planned in the study design, resulting in variations in group size. Due to the non-predictable onset of canine IVDH, the group could neither be age nor gender matched, possibly influencing the results. Furthermore, most of our patients were presented at a late stage of the disease, which may explain why we might have missed the peak expression of some cytokines in the acute stage of the disease.

\section{CONCLUSION}

Inflammation in the epidural compartment plays a central role in the pathophysiology of canine IVD herniation and significantly influences the course and outcome of the disease. Working with a clinical canine model not only provides the possibility to overcome animal experimentation, but furthermore allows (different from human studies) the analysis of adjacent, NA discs. Although expression of key cytokines found in human IVDs could also be demonstrated in canine tissue, the inflammatory mechanisms accompanying IVDH in dogs partially diverge from humans. These differences need to be considered when using dogs as a model for human medicine. In dogs, IL-6 seems to play an important pathological role, but further investigations on IL-6 as a potential therapeutic target in canine patients will be needed, especially when considering its likely ambivalent role. 


\section{ETHICS STATEMENT}

This study was carried out in accordance with the recommendations of "Animal Research Committee: Tierversuchsbewilligung BE 14/12, Switzerland." The protocol was approved by the "Animal Research Committee: Tierversuchsbewilligung BE 14/12, Switzerland." Furthermore, all patient-owners signed an owner consent form.

\section{AUTHOR CONTRIBUTIONS}

MM contributed to the conception and design, acquisition and data, analysis and interpretation of data, drafting of the manuscript, critical revision of the manuscript for important intellectual content, and statistical analysis. SF contributed to the analysis and interpretation of data, drafting of the manuscript, critical revision of the manuscript for important intellectual content, and the statistical analysis. DS contributed to the conception and design, critical revision of the manuscript and intellectual content, funding, and final approval of the version to

\section{REFERENCES}

1. Hoy D, March L, Brooks P, Blyth F, Woolf A, Bain C, et al. The global burden of low back pain: estimates from the Global Burden of Disease 2010 study. Ann Rheum Dis (2014) 73:968-74. doi:10.1136/annrheumdis-2013-204428

2. Luoma K, Riihimäki H, Luukkonen R, Raininko R, Viikari-Juntura E, Lamminen A. Low back pain in relation to lumbar disc degeneration. Spine (Phila Pa 1976) (2000) 25:487-92. doi:10.1097/00007632-20000215000016

3. Kaapa E, Vanharanta H. Intervertebral disk degeneration - a central cause of back problems. Duodecim (1991) 107:1603-11.

4. Vanharanta H, Guyer RD, Ohnmeiss DD, Stith WJ, Sachs BL, Aprill C, et al. Disc deterioration in low-back syndromes. A prospective, multi-center CT/discography study. Spine (Phila $\mathrm{Pa}$ 1976) (1988) 13:1349-51. doi:10.1097/00007632-198812000-00003

5. Lyons G, Eisenstein SM, Sweet MB. Biochemical changes in intervertebral disc degeneration. Biochim Biophys Acta (1981) 673:443-53. doi:10.1016/0304-4165(81)90476-1

6. Freemont AJ, Peacock TE, Goupille P, Hoyland JA, O’Brien J, Jayson MIV. Nerve ingrowth into diseased intervertebral disc in chronic back pain. Lancet (1997) 350:178-81. doi:10.1016/S0140-6736(97)02135-1

7. Kepler CK, Markova DZ, Hilibrand AS, Vaccaro AR, Risbud MV, Albert TJ, et al. Substance P stimulates production of inflammatory cytokines in human disc cells. Spine (Phila Pa 1976) (2013) 38:E1291-9. doi:10.1097/ BRS.0b013e3182a42bc2

8. Wuertz K, Haglund L. Inflammatory mediators in intervertebral disk degeneration and discogenic pain. Global Spine J (2013) 3:175-84. doi:10.1055/s-00331347299

9. Kepler CK, Markova DZ, Dibra F, Yadla S, Vaccaro AR, Risbud MV, et al. Expression and relationship of proinflammatory chemokine RANTES/CCL5 and cytokine IL-1 $\beta$ in painful human intervertebral discs. Spine (Phila Pa 1976) (2013) 38:873-80. doi:10.1097/BRS.0b013e318285ae08

10. Andrade P, Hoogland G, Garcia MA, Steinbusch HW, Daemen MA, VisserVandewalle V. Elevated IL-1b and IL-6 levels in lumbar herniated discs in patients with sciatic pain. Eur Spine J (2013) 22:714-20. doi:10.1007/ s00586-012-2502-x

11. Cuéllar JM, Borges PM, Cuéllar VG, Yoo A, Scuderi GJ, Yeomans DC. Cytokine expression in the epidural space: a model of noncompressive disc herniation-induced inflammation. Spine (Phila Pa 1976) (2013) 38:17-23. doi:10.1097/BRS.0b013e3182604baa

12. De Souza Grava AL, Ferrari LF, Defino HLA. Cytokine inhibition and time-related influence of inflammatory stimuli on the hyperalgesia induced be published. AK contributed to acquisition and data, interpretation and analysis of data, critical revision and administrative, technical, or material support. FF and KW-K contributed equally to the conception and design, analysis and interpretation of data, drafting of the manuscript, critical revision of the manuscript for important intellectual content, obtaining funding, administrative, technical or material support, supervision, and final approval of the version to be published. All authors agreed to be accountable for all aspects of the work in ensuring that questions related to the accuracy or integrity of any part of the work are appropriately investigated and resolved. We thank Prof. Dr. Michael Stoffel (Vetsuisse Bern, Veterinary Anatomy) for his support with histology.

\section{FUNDING}

The study was funded and supported with $37,500 \$$ by The Competence Center for Applied Biotechnology and Molecular Medicine Start-up Grant of the University of Zurich, Switzerland. Heel GmbH financially supported the salary of MM.

by the nucleus pulposus. Eur Spine J (2012) 21:537-45. doi:10.1007/ s00586-011-2027-8

13. Studer RK, Vo N, Sowa G, Ondeck C, Kang J. Human nucleus pulposus cells react to IL-6: independent actions and amplification of response to IL-1 and TNF- $\alpha$. Spine (Phila Pa 1976) (2011) 36:593-9. doi:10.1097/ BRS.0b013e3181da38d5

14. Vo NV, Sowa GA, Kang JD, Seidel C, Studer RK. Prostaglandin E2 and prostaglandin F2alpha differentially modulate matrix metabolism of human nucleus pulposus cells. J Orthop Res (2010) 28:1259-66. doi:10.1002/jor.21157

15. Kim JH, Studer RK, Sowa GA, Vo NV, Kang JD. Activated macrophage-like THP-1 cells modulate anulus fibrosus cell production of inflammatory mediators in response to cytokines. Spine (Phila Pa 1976) (2008) 33:2253-9. doi:10.1097/BRS.0b013e318182c35f

16. Abe Y, Akeda K, An HS, Aoki Y, Pichika R, Muehleman C, et al. Proinflammatory cytokines stimulate the expression of nerve growth factor by human intervertebral disc cells. Spine (Phila Pa 1976) (2007) 32:635-42. doi:10.1097/01.brs.0000257556.90850.53

17. Le Maitre CL, Hoyland JA, Freemont AJ. Catabolic cytokine expression in degenerate and herniated human intervertebral discs: IL-1beta and TNFalpha expression profile. Arthritis Res Ther (2007) 9:R77. doi:10.1186/ar2275

18. Yoshida M, Nakamura T, Sei A, Kikuchi T, Takagi K, Matsukawa A. Intervertebral disc cells produce tumor necrosis factor alpha, interleukin-1beta, and monocyte chemoattractant protein-1 immediately after herniation: an experimental study using a new hernia model. Spine (Phila Pa 1976) (2005) 30:55-61. doi:10.1097/01.brs.0000149194.17891.bf

19. Ahn S-H, Cho Y-W, Ahn M-W, Jang S-H, Sohn Y-K, Kim H-S. mRNA expression of cytokines and chemokines in herniated lumbar intervertebral discs. Spine (Phila Pa 1976) (2002) 27:911-7. doi:10.1097/00007632-200205010-00005

20. Miyamoto H, Saura R, Harada T, Doita M, Mizuno K. The role of cyclooxygenase-2 and inflammatory cytokines in pain induction of herniated lumbar intervertebral disc. Kobe J Med Sci (2000) 46(1-2):13-28.

21. Nygaard OP, Mellgren SI, Osterud B. The inflammatory properties of contained and noncontained lumbar disc herniation. Spine (Phila Pa 1976) (1997) 22:2484-8. doi:10.1097/00007632-199711010-00004

22. Takahashi H, Suguro T, Okazima Y, Motegi M, Okada Y, Kakiuchi T. Inflammatory cytokines in the herniated disc of the lumbar spine. Spine (Phila Pa 1976) (1996) 21:218-24. doi:10.1097/00007632-199601150-00011

23. KangJD,GeorgescuHI,McIntyre-LarkinL,Stefanovic-RacicM,DonaldsonWF, Evans CH. Herniated lumbar intervertebral discs spontaneously produce matrix metalloproteinases, nitric oxide, interleukin-6, and prostaglandin E2. Spine (Phila Pa 1976) (1996) 21:271-7. doi:10.1097/00007632-19960201000004 
24. Popovich PG, Jones TB. Manipulating neuroinflammatory reactions in the injured spinal cord: back to basics. Trends Pharmacol Sci (2003) 24:13-7. doi:10.1016/S0165-6147(02)00006-8

25. Igarashi A, Kikuchi S, Konno S, Olmarker K. Inflammatory cytokines released from the facet joint tissue in degenerative lumbar spinal disorders. Spine (Phila Pa 1976) (2004) 29:2091-5. doi:10.1097/01.brs.0000141265. 55411.30

26. Igarashi A, Kikuchi SI, Konno SI. Correlation between inflammatory cytokines released from the lumbar facet joint tissue and symptoms in degenerative lumbar spinal disorders. J Orthop Sci (2007) 12:154-60. doi:10.1007/ s00776-006-1105-y

27. Wuertz K, Vo N, Kletsas D, Boos N. Inflammatory and catabolic signalling in intervertebral discs: the roles of NF-KB and map kinases. Eur Cell Mater (2012) 23:103-20. doi:10.22203/eCM.v023a08

28. Le Maitre CL, Freemont AJ, Hoyland JA. The role of interleukin-1 in the pathogenesis of human intervertebral disc degeneration. Arthritis Res Ther (2005) 7:R732-45. doi:10.1186/ar1732

29. Fardon DF, Milette PC. Nomenclature and classification of lumbar disc pathology. Spine (Phila Pa 1976) (2001) 26:E93-113. doi:10.1016/j.spinee.2014.04.022

30. Doita M, Kanatani T, Harada T, Mizuno K. Immunohistologic study of the ruptured intervertebral disc of the lumbar spine. Spine (Phila Pa 1976) (1996) 21:235-41. doi:10.1097/00007632-199601150-00015

31. Doita M, Kanatani T, Ozaki T, Matsui N, Kurosaka M, Yoshiya S. Influence of macrophage infiltration of herniated disc tissue on the production of matrix metalloproteinases leading to disc resorption. Spine (Phila Pa 1976) (2001) 26:1522-7. doi:10.1097/00007632-200107150-00004

32. Genevay S, Finckh A, Payer M, Mezin F, Tessitore E, Gabay C, et al. Elevated levels of tumor necrosis factor-alpha in periradicular fat tissue in patients with radiculopathy from herniated disc. Spine (Phila Pa 1976) (2008) 33:2041-6. doi:10.1097/BRS.0b013e318183bb86

33. Kawaguchi S, Yamashita T, Katahira G, Yokozawa H, Torigoe T, Sato N. Chemokine profile of herniated intervertebral discs infiltrated with monocytes and macrophages. Spine (Phila Pa 1976) (2002) 27:1511-6. doi:10.1097/ 00007632-200207150-00006

34. Kawaguchi S, Yamashita T, Yokogushi K, Murakami T, Ohwada O, Sato N. Immunophenotypic analysis of the inflammatory infiltrates in herniated intervertebral discs. Spine (Phila Pa 1976) (2001) 26:1209-14. doi:10.1097/00007632-200106010-00008

35. Minamide A, Hashizume H, Yoshida M, Kawakami M, Hayashi N, Tamaki T. Effects of basic fibroblast growth factor on spontaneous resorption of herniated intervertebral discs. An experimental study in the rabbit. Spine (Phila Pa 1976) (1999) 24:940-5. doi:10.1097/00007632-199905150-00003

36. Yamashita M, Ohtori S, Koshi T, Inoue G, Yamauchi K, Suzuki M, et al. Tumor necrosis factor-alpha in the nucleus pulposus mediates radicular pain, but not increase of inflammatory peptide, associated with nerve damage in mice. Spine (Phila Pa 1976) (2008) 33:1836-42. doi:10.1097/BRS.0b013e31817bab2a

37. Zhou G, Dai L, Jiang X, Ma Z, Ping J, Li J, et al. Effects of human midkine on spontaneous resorption of herniated intervertebral discs. Int Orthop (2010) 34:103-8. doi:10.1007/s00264-009-0740-2

38. Schroeder GD, Guyre CA, Vaccaro AR. The epidemiology and pathophysiology of lumbar disc herniations. Semin Spine Surg (2016) 28:2-7. doi:10.1053/j. semss.2015.08.003

39. Goupille P, Jayson MIV, Valat JP, Freemont AJ. The role of inflammation in disk herniation-associated radiculopathy. Semin Arthritis Rheum (1998) 28:60-71. doi:10.1016/S0049-0172(98)80029-2

40. Kalb S, Martirosyan NL, Kalani MYS, Broc GG, Theodore N. Genetics of the degenerated intervertebral disc. World Neurosurg (2012) 77:491-501. doi:10.1016/j.wneu.2011.07.014

41. Yu-Ping Kao P, Chan D, Samartzis D, Sham PC, Song YQ. Genetics of lumbar disk degeneration: technology, study designs, and risk factors. Orthop Clin North Am (2011) 42:479-86. doi:10.1016/j.ocl.2011.07.011

42. Bachmeier BE, Nerlich AG, Weiler C, Paesold G, Jochum M, Boos N. Analysis of tissue distribution of TNF-alpha, TNF-alpha-receptors, and the activating TNF-alpha-converting enzyme suggests activation of the TNF-alpha system in the aging intervertebral disc. Ann N Y Acad Sci (2007) 1096:44-54. doi:10.1196/annals.1397.069

43. Di Virgilio F. New pathways for reactive oxygen species generation in inflammation and potential novel pharmacological targets. Curr Pharm Des (2004) 10:1647-52. doi:10.2174/1381612043384727
44. Finkel T, Holbrook NJ. Oxidants, oxidative stress and the biology of ageing. Nature (2000) 408:239-47. doi:10.1038/35041687

45. Ogawa T, Matsuzaki H, Uei H, Nakajima S, Tokuhashi Y, Esumi M. Alteration of gene expression in intervertebral disc degeneration of passive cigarette-smoking rats: separate quantitation in separated nucleus pulposus and annulus fibrosus. Pathobiology (2005) 72:146-51. doi:10.1159/ 000084118

46. Liuke M, Solovieva S, Lamminen A, Luoma K, Leino-Arjas P, Luukkonen R, et al. Disc degeneration of the lumbar spine in relation to overweight. Int J Obes (2005) 29:903-8. doi:10.1038/sj.ijo.0802974

47. Samartzis D, Karppinen J, Chan D, Luk KDK, Cheung KMC. The association of lumbar intervertebral disc degeneration on magnetic resonance imaging with body mass index in overweight and obese adults: a population-based study. Arthritis Rheum (2012) 64:1488-96. doi:10.1002/art.33462

48. Takatalo J, Karppinen J, Taimela S, Niinimäki J, Laitinen J, Sequeiros RB, et al. Association of abdominal obesity with lumbar disc degeneration - a magnetic resonance imaging study. PLoS One (2013) 8:e56244. doi:10.1371/ journal.pone. 0056244

49. Hamminga EA, van der Lely AJ, Neumann HAM, Thio HB. Chronic inflammation in psoriasis and obesity: implications for therapy. Med Hypotheses (2006) 67:768-73. doi:10.1016/j.mehy.2005.11.050

50. Singh K, Masuda K, An HS. Animal models for human disc degeneration. Spine J (2005) 5:267S-79S. doi:10.1016/j.spinee.2005.02.016

51. Yamada K. The dynamics of experimental posture. Experimental study of intervertebral disc herniation in bipedal animals. Tokushima J Exp Med (1962) 8:350-61.

52. Bergknut N, Rutges JPHJ, Kranenburg H-JC, Smolders LA, Hagman R, Smidt $\mathrm{H}-\mathrm{J}$, et al. The dog as an animal model for intervertebral disc degeneration? Spine (Phila Pa 1976) (2012) 37:351-8. doi:10.1097/BRS.0b013e31821e5665

53. Levine JM, Levine GJ, Porter BF, Topp K, Noble-Haeusslein LJ. Naturally occurring disk herniation in dogs: an opportunity for pre-clinical spinal cord injury research. J Neurotrauma (2011) 28:675-88. doi:10.1089/ neu.2010.1645

54. Bergknut N, Egenvall A, Hagman R, Gustås P, Hazewinkel HAW, Meij BP, et al. Incidence of intervertebral disk degeneration-related diseases and associated mortality rates in dogs. J Am Vet Med Assoc (2012) 240:1300-9. doi:10.2460/ javma.240.11.1300

55. Bray J, Burbidge $\mathrm{H}$. The canine intervertebral disk: part one: structure and function. JAm Anim Hosp Assoc (1998) 34:55-63. doi:10.5326/1547331734-1-55

56. Priester WA. Canine intervertebral disc disease - occurrence by age, breed, and sex among 8,117 cases. Theriogenology (1976) 6:293-303. doi:10.1016/ 0093-691X(76)90021-2

57. Smolders LA, Bergknut N, Grinwis GCM, Hagman R, Lagerstedt AS, Hazewinkel HAW, et al. Intervertebral disc degeneration in the dog. Part 2: chondrodystrophic and non-chondrodystrophic breeds. Vet J (2013) 195:292-9. doi:10.1016/j.tvil.2012.10.011

58. Bray J, Burbidge H. The canine intervertebral disk. Part two: degenerative changes - nonchondrodystrophoid versus chondrodystrophoid disks. J Am Anim Hosp Assoc (1998) 34:135-44. doi:10.5326/15473317-34-2-135

59. Hansen H. A pathologic-anatomical interpretation of disc degeneration in dogs. Acta Orthop Scand (1951) 20:280-93. doi:10.3109/17453675108991175

60. Lund EM, Armstrong PJ, Kirk CA, Klausner JS. Prevalence and risk factors for obesity in adult dogs from private US veterinary practices. J Appl Res Vet Med (2006) 4:177-86.

61. Edney AT, Smith PM. Study of obesity in dogs visiting veterinary practices in the United Kingdom. Vet Rec (1986) 118:391-6. doi:10.1136/vr.118. 14.391

62. Packer RMA, Hendricks A, Volk HA, Shihab NK, Burn CC. How long and low can you go? Effect of conformation on the risk of thoracolumbar intervertebral disc extrusion in domestic dogs. PLoS One (2013) 8:e69650. doi:10.1371/ journal.pone. 0069650

63. Spitzbarth I, Bock P, Haist V, Stein VM, Tipold A, Wewetzer K, et al. Prominent microglial activation in the early proinflammatory immune response in naturally occurring canine spinal cord injury. J Neuropathol Exp Neurol (2011) 70:703-14. doi:10.1097/NEN.0b013e3182270f8e

64. Karli P, Martlé V, Bossens K, Summerfield A, Doherr MG, Turner P, et al. Dominance of chemokine ligand 2 and matrix metalloproteinase- 2 and -9 and suppression of pro-inflammatory cytokines in the epidural compartment after 
intervertebral disc extrusion in a canine model. Spine J (2014) 14:2976-84. doi:10.1016/j.spinee.2014.05.021

65. Skogstrand K, Ekelund CK, Thorsen P, Vogel I, Jacobsson B, NørgaardPedersen B, et al. Effects of blood sample handling procedures on measurable inflammatory markers in plasma, serum and dried blood spot samples. J Immunol Methods (2008) 336:78-84. doi:10.1016/j.jim.2008.04.006

66. Riches P, Gooding R, Millar BC, Rowbottom AW. Influence of collection and separation of blood samples on plasma IL-1, IL- 6 and TNF- $\alpha$ concentrations. J Immunol Methods (1992) 153:125-31. doi:10.1016/0022-1759 (92)90314-J

67. Keustermans GCE, Hoeks SBE, Meerding JM, Prakken BJ, de Jager W. Cytokine assays: an assessment of the preparation and treatment of blood and tissue samples. Methods (2013) 61:10-7. doi:10.1016/j.ymeth.2013.04.005

68. Hooper R. Extradural haemorrhages of the posterior fossa. Br J Surg (1954) 42:19. doi:10.1002/bjs.18004217103

69. Su T-M, Lee T-H, Lee T-C, Cheng C-H, Lu C-H. Acute clinical deterioration of posterior fossa epidural hematoma: clinical features, risk factors and outcome. Chang Gung Med J (2012) 35(3):271-80.

70. Fadda A, Oevermann A, Vandevelde M, Doherr MG, Forterre F, Henke D. Clinical and pathological analysis of epidural inflammation in intervertebral disk extrusion in dogs. J Vet Intern Med (2013) 27:924-34. doi:10.1111/ jvim. 12095

71. Penning V, Platt SR, Dennis R, Cappello R, Adams V. Association of spinal cord compression seen on magnetic resonance imaging with clinical outcome in 67 dogs with thoracolumbar intervertebral disc extrusion. J Small Anim Pract (2006) 47:644-50. doi:10.1111/j.1748-5827.2006.00252.x

72. Goni R, García P, Foissac S. The qPCR data statistical analysis. Integromics White Pap (2009) 1:1-9.

73. Bergknut N, Auriemma E, Wijsman S, Voorhout G, Hagman R, Lagerstedt AS, et al. Evaluation of intervertebral disk degeneration in chondrodystrophic and nonchondrodystrophic dogs by use of Pfirrmann grading of images obtained with low-field magnetic resonance imaging. Am J Vet Res (2011) 72:893-8. doi:10.2460/ajvr.72.7.893

74. Kranenburg HC, Grinwis GCM, Bergknut N, Gahrmann N, Voorhout G, Hazewinkel HAW, et al. Intervertebral disc disease in dogs - part 2: comparison of clinical, magnetic resonance imaging, and histological findings in 74 surgically treated dogs. Vet $J$ (2013) 195:164-71. doi:10.1016/j.tvjl. 2012.06.001

75. Willems N, Tellegen AR, Bergknut N, Creemers LB, Wolfswinkel J, Freudigmann $\mathrm{C}$, et al. Inflammatory profiles in canine intervertebral disc degeneration. BMC Vet Res (2016) 12:10. doi:10.1186/s12917-016-0635-6

76. BurkeJG, Watson RW, McCormackD, Dowling FE, Walsh MG, Fitzpatrick JM. Intervertebral discs which cause low back pain secrete high levels of proinflammatory mediators. J Bone Joint Surg Br (2002) 84:196-201. doi:10.1302/0301620X.84B2.12511

77. Taylor AR, Welsh CJ, Young C, Spoor E, Kerwin SC, Griffin JF, et al. Cerebrospinal fluid inflammatory cytokines and chemokines in naturally occurring canine spinal cord injury. J Neurotrauma (2014) 31:1561-9. doi:10.1089/neu.2014.3405

78. Takada T, Nishida K, Doita M, Miyamoto H, Kurosaka M. Interleukin-6 production is upregulated by interaction between disc tissue and macrophages. Spine (Phila Pa 1976) (2004) 29:1089-92; discussion 1093. doi:10.1097/00007632-200405150-00007

79. Altun I. Cytokine profile in degenerated painful intervertebral disc: variability with respect to duration of symptoms and type of disease. Spine J (2016) 16:857-61. doi:10.1016/j.spinee.2016.03.019

80. Scheller J, Chalaris A, Schmidt-Arras D, Rose-John S. The pro- and anti-inflammatory properties of the cytokine interleukin-6. Biochim Biophys Acta (2011) 1813:878-88. doi:10.1016/j.bbamcr.2011.01.034

81. Watkins LR, Maier SF, Goehler LE. Immune activation: the role of pro-inflammatory cytokines in inflammation, illness responses and pathological pain states. Pain (1995) 63:289-302. doi:10.1016/0304-3959(95)00186-7

82. Xing Z, Gauldie J, Cox G, Baumann H, Jordana M, Lei XF, et al. IL-6 is an antiinflammatory cytokine required for controlling local or systemic acute inflammatory responses. J Clin Invest (1998) 101:311-20. doi:10.1172/ JCI1368

83. Kishimoto T. IL-6: from its discovery to clinical applications. Int Immunol (2010) 22:347-52. doi:10.1093/intimm/dxq030
84. Ray A, Tatter SB, May LT, Sehgal PB. Activation of the human "beta 2-interferon/hepatocyte-stimulating factor/interleukin 6" promoter by cytokines, viruses, and second messenger agonists. Proc Natl Acad Sci U S A (1988) 85:6701-5. doi:10.1073/pnas.85.18.6701

85. Zhang XG, Klein B, Bataille R. Interleukin- 6 is a potent myeloma-cell growth factor in patients with aggressive multiple myeloma. Blood (1989) 74:11-3.

86. Navarro S, Debili N, Bernaudin JF, Vainchenker W, Doly J. Regulation of the expression of IL-6 in human monocytes. J Immunol (1989) 142:4339-45.

87. Shamji MF, Setton LA, Jarvis W, So S, Chen J, Jing L, et al. Proinflammatory cytokine expression profile in degenerated and herniated human intervertebral disc tissues. Arthritis Rheum (2010) 62:1974-82. doi:10.1002/art.27444

88. Séguin CA, Pilliar RM, Roughley PJ, Kandel RA. Tumor necrosis factor-alpha modulates matrix production and catabolism in nucleus pulposus tissue. Spine (Phila Pa 1976) (2005) 30:1940-8. doi:10.1097/01.brs.0000176188.40263.f9

89. Le Maitre CL, Hoyland JA, Freemont AJ. Interleukin-1 receptor antagonist delivered directly and by gene therapy inhibits matrix degradation in the intact degenerate human intervertebral disc: an in situ zymographic and gene therapy study. Arthritis Res Ther (2007) 9:R83. doi:10.1186/ar2282

90. Wang J, Markova D, Anderson DG, Zheng Z, Shapiro IM, Risbud MV. TNF-alpha and IL-1beta promote a disintegrin-like and metalloprotease with thrombospondin type I motif-5-mediated aggrecan degradation through syndecan-4 in intervertebral disc. J Biol Chem (2011) 286:39738-49. doi:10.1074/jbc.M111.264549

91. Purmessur D, Freemont AJ, Hoyland JA. Expression and regulation of neurotrophins in the nondegenerate and degenerate human intervertebral disc. Arthritis Res Ther (2008) 10:R99. doi:10.1186/ar2487

92. Freemont AJ, Watkins A, Le Maitre C, Baird P, Jeziorska M, Knight MT, et al. Nerve growth factor expression and innervation of the painful intervertebral disc. J Pathol (2002) 197:286-92. doi:10.1002/path.1108

93. Olmarker K, Larsson K. Tumor necrosis factor alpha and nucleus-pulposus-induced nerve root injury. Spine (Phila Pa 1976) (1998) 23:2538-44 doi:10.1097/00007632-199812010-00008

94. Kaminska B. MAPK signalling pathways as molecular targets for anti-inflammatory therapy - from molecular mechanisms to therapeutic benefits. Biochim Biophys Acta (2005) 1754:253-62. doi:10.1016/j.bbapap.2005.08.017

95. Ulrich JA, Liebenberg EC, Thuillier DU, Lotz JC. ISSLS prize winner: repeated disc injury causes persistent inflammation. Spine (Phila Pa 1976) (2007) 32:2812-9. doi:10.1097/BRS.0b013e31815b9850

96. Séguin CA, Bojarski M, Pilliar RM, Roughley PJ, Kandel RA. Differential regulation of matrix degrading enzymes in a TNF $\alpha$-induced model of nucleus pulposus tissue degeneration. Matrix Biol (2006) 25:409-18. doi:10.1016/j. matbio.2006.07.002

97. Studer RK, Gilbertson LG, Georgescu H, Sowa G, Vo N, Kang JD. p38 MAPK inhibition modulates rabbit nucleus pulposus cell response to IL-1. J Orthop Res (2008) 26:991-8. doi:10.1002/jor.20604

98. Klawitter M, Quero L, Klasen J, Liebscher T, Nerlich A, Boos N, et al. Triptolide exhibits anti-inflammatory, anti-catabolic as well as anabolic effects and suppresses TLR expression and MAPK activity in IL-1beta treated human intervertebral disc cells. Eur Spine J (2012) 21:850-9. doi:10.1007/ s00586-011-1919-y

99. Wuertz K, Quero L, Sekiguchi M, Klawitter M, Nerlich A, Konno S-I, et al. The red wine polyphenol resveratrol shows promising potential for the treatment of nucleus pulposus-mediated pain in vitro and in vivo. Spine (Phila Pa 1976) (2011) 36:E1373-84. doi:10.1097/BRS.0b013e318221e655

100. Wang J, Chen H, Cao P, Wu X, Zang F, Shi L, et al. Inflammatory cytokines induce caveolin- $1 / \beta$-catenin signalling in rat nucleus pulposus cell apoptosis through the p38 MAPK pathway. Cell Prolif (2016) 49:362-72. doi:10.1111/ cpr.12254

101. Mavrogonatou E, Kletsas D. Effect of varying osmotic conditions on the response of bovine nucleus pulposus cells to growth factors and the activation of the ERK and Akt pathways. J Orthop Res (2010) 28:1276-82. doi:10.1002/ jor.21140

102. Zhu Y, Liu JT, Yang LY, Du WP, Li XC, Qian X, et al. P38 mitogen-activated protein kinase inhibition modulates nucleus pulposus cell apoptosis in spontaneous resorption of herniated intervertebral discs: an experimental study in rats. Mol Med Rep (2016) 13:4001-6. doi:10.3892/mmr.2016.5039

103. Yang C, Cao P, Gao Y, Wu M, Lin Y, Tian Y, et al. Differential expression of p38 MAPK alpha, beta, gamma, delta isoforms in nucleus pulposus modulates 
macrophage polarization in intervertebral disc degeneration. Sci Rep (2016) 6:22182. doi:10.1038/srep22182

104. Park JJ, Moon HJ, Park JH, Kwon TH, Park Y-K, Kim JH. Induction of proinflammatory cytokine production in intervertebral disc cells by macrophage-like THP-1 cells requires mitogen-activated protein kinase activity. J Neurosurg Spine (2016) 24:167-75. doi:10.3171/2015.3.SPINE14729

Conflict of Interest Statement: KW-K (08/03/2017) Relationships Pertaining to Submitted Manuscript-Money payed to the institution: 37.500 \$ (CABMM Start-up Grant) Relevant financial activities outside the submitted workConsulting Money payed to you: 85.000 \$ (Schön Clinic Group). All other authors declare that the research was conducted in the absence of any commercial or financial relationships that could be construed as a potential conflict of interest.

Copyright ( 2017 Monchaux, Forterre, Spreng, Karol, Forterre and Wuertz-Kozak. This is an open-access article distributed under the terms of the Creative Commons Attribution License (CC BY). The use, distribution or reproduction in other forums is permitted, provided the original author(s) or licensor are credited and that the original publication in this journal is cited, in accordance with accepted academic practice. No use, distribution or reproduction is permitted which does not comply with these terms. 